Paweł Felis*

\title{
Ocena funkcjonowania podatków od dochodów osób fizycznych oraz osób prawnych w Polsce
}

\begin{abstract}
Personal and corporate income taxes in Poland: The article looks at the selected issues related to personal income tax and corporate income tax in Poland. The author discusses the legal framework of taxes and presents empirical data analysis. First, he examines whether there is a correlation between the legislative changes to income taxes and the state budget revenues. Next, he discusses regulations of income taxes which are of particular importance for the entrepreneurial activities. Finally, the efficiency of the personal income tax redistribution is asserted.
\end{abstract}

\section{Słowa kluczowe: podatek dochodowy · podatek dochodowy od osób fizycznych · podatek dochodowy od osób prawnych \\ Keywords: income tax $\cdot$ personal income tax $\cdot$ corporate income tax \\ * Doktor hab. nauk ekonomicznych, profesor nadzwyczajny w Instytucie Finansów, Szkoła Główna Handlowaw Warszawie; e-mail: pfelis@sgh.waw.pl.}

\section{Wstęp}

Obowiązujące obecnie w Polsce rozwiązania w zakresie opodatkowania dochodów swój kształt zawdzięczają reformom podatkowym z przełomu lat 80. i 90. XX wieku, kiedy to wprowadzono m.in. jednolity podatek dochodowy od osób prawnych ${ }^{1}$ oraz powszechny podatek dochodowy od osób fizycznych. Celem reformy było unowocześnienie i wzmocnienie polskiego systemu podatkowego oraz przybliżenie go do standardów państw Europy Zachodniej. Rozpatrując problem opodatkowania dochodów, nie można jednak - jak słusznie zauważa J. Kulicki - ograniczać się do wymienionych podatków² ${ }^{2}$ W polskim

1 Do końca 1988 r. działające w Polsce podmioty gospodarcze były opodatkowane podatkiem dochodowym wg kryterium uspołecznienia.

2 J. Kulicki, Reforma opodatkowania dochodów [w:] Dylematy reformy systemu podatkowego w Polsce, red. H. Dzwonkowski, J. Kulicki, Wydawnictwo Sejmowe, Warszawa 2016, s. 328-329. 
prawie podatkowym funkcjonują bowiem i formy ryczałtowe, podatki różnie klasyfikowane przez doktrynę, a dotyczące dochodów z określonych działalności (rolniczej, leśnej) ${ }^{3}$, a także podatek od spadków i darowizn ${ }^{4}$.

Stąd obecny model opodatkowania dochodów osób fizycznych, osób prawnych oraz jednostek organizacyjnych niemających osobowości prawnej może być przedstawiany i analizowany w szerokim i wąskim ujęciu. W pierwszym wypadku dla osób fizycznych ustawodawca przewidział następujące tytuły podatkowe: podatek dochodowy, podatek rolny, podatek leśny, podatek od spadków i darowizn regulowane sześcioma ustawami (ustawą o podatku dochodowym od osób fizycznych ${ }^{5}$, ustawą o zryczałtowanym podatku dochodowym od niektórych przychodów osiąganych przez osoby fizyczne $e^{6}$, ustawą o podatku tonażowym ${ }^{7}$, ustawą o podatku rolnym ${ }^{8}$, ustawą o podatku leśnym ${ }^{9}$ oraz ustawą o podatku od spadków i darowizn ${ }^{10}$ ). Natomiast dla osób prawnych i jednostek organizacyjnych nieposiadających osobowości prawnej są to: podatek dochodowy, podatek rolny i podatek leśny regulowane w czterech ustawach (ustawie o podatku dochodowym od osób prawnych ${ }^{11}$, ustawie o podatku tonażowym, ustawie o podatku rolnym oraz ustawie o podatku leśnym). W drugim wypadku, ograniczając się do dochodów opodatkowanych podatkiem dochodowym, można wyróżnić pięć form opodatkowania dla osób fizycznych (zasady ogólne, regulowane ustawą o podatku dochodowym od osób fizycznych; ryczałt ewidencjonowany, karta podatkowa i ryczałt od przychodów

${ }_{3}^{3}$ Przykładem są podatek rolny i leśny, które na ogół klasyfikowane są - ze względu na uzależnienie powstania obowiązku podatkowego od faktu posiadania gruntu, posiadania lasu - jako podatki majątkowe. Zob. np. P. Felis, Podatki od nieruchomości a polityka podatkowa gmin w Polsce, Wydawnictwo SGH, Warszawa 2015. Nie można jednak pominąć faktu, że ze względu na uzależnienie wysokości podatku rolnego od jakości gleby oraz ceny żyta, a podatku leśnego od ceny drewna, wymienione daniny mają pewne cechy podatku dochodowego.

${ }^{4} \mathrm{Z}$ opodatkowania podatkiem dochodowym od osób fizycznych wyłączone są m.in. przychody podlegające opodatkowaniu podatkiem od spadków i darowizn. Inaczej jest natomiast w odniesieniu do podmiotów podlegających opodatkowaniu na podstawie ustawy o podatku dochodowym od osób prawnych. Przychody uzyskane w drodze zapisu lub darowizny podlegają opodatkowaniu właśnie podatkiem dochodowym od osób prawnych.

${ }^{5}$ Ustawa z 26 lipca 1991 r. o podatku dochodowym od osób fizycznych, t.j. Dz.U. 2016, poz. 2032, ze zm.); dalej: PIT.

${ }^{6}$ Ustawa z 20 listopada 1998 r. o zryczałtowanym podatku dochodowym od niektórych przychodów osiąganych przez osoby fizyczne, t.j. Dz.U. 2017, poz. 2157.

7 Ustawa z 24 sierpnia 2006 r. o podatku tonażowym, t.j. Dz.U. 2014, poz. 511, ze zm.

8 Ustawa z 15 listopada 1984 r. z podatku rolnym, t.j. Dz.U. 2017, poz. 1892.

9 Ustawa z 30 października 2002 r. o podatku leśnym, t.j. Dz.U. 2017, poz. 1821.

10 Ustawa z 28 lipca 1983 r. o podatku od spadków i darowizn, t.j. Dz.U. 2017, poz. 833, ze zm.

11 Ustawa z 15 lutego 1992 r. o podatku dochodowym od osób prawnych, t.j. Dz.U. 2016, poz. 1888 ze zm.; dalej: CIT. 
osób duchownych, regulowane w ustawie o zryczałtowanym podatku dochodowym od niektórych przychodów osiąganych przez osoby fizyczne; podatek tonażowy, regulowany w ustawie o podatku tonażowym) oraz dwie formy opodatkowania dla osób prawnych (zasady ogólne, regulowane w ustawie o podatku dochodowym od osób prawnych; podatek tonażowy, regulowany w ustawie o podatku tonażowym).

Tematem artykułu - ze względu na jego ograniczone ramy - jest analiza i ocena jedynie dwóch podatków dochodowych - podatku dochodowego od osób fizycznych (PIT) oraz podatku dochodowego od osób prawnych (CIT). $\mathrm{W}$ niniejszym opracowaniu wyselekcjonowano określone regulacje i ich najważniejsze zmiany, w zakresie:

- CIT i PIT, które wpływały na ich efektywność fiskalną, co umożliwiło odpowiedź na pytanie, czy występowała zależność między przeprowadzonymi przez ustawodawcę zmianami w podatkach dochodowych a poziomem wpływów budżetowych,

- CIT i PIT, które wpływały na poziom obciążeń podatkowych przedsiębiorstw, dzięki temu możliwa była odpowiedź na pytanie, jakie to miało znaczenie dla aktywności gospodarczej przedsiębiorstw,

- PIT, które były istotne z punktu widzenia prospołecznego nastawienia polityki podatkowej, co umożliwiło odpowiedź na pytanie dotyczące skuteczności redystrybucji podatku dochodowego od osób fizycznych.

Przeprowadzone w artykule analizy oparte są w większości - ze względu na ich dostępność - na danych z okresu 2000-2016. Relatywnie długi przedział czasowy badania umożliwił rozpoznanie zmian w zakresie przepisów regulujących podatki dochodowe i stopnia ich złożoności, a także zbadanie dynamiki wpływów z ich tytułu oraz identyfikację wpływających na nie czynników. Pozwoliło to na wskazanie zalet i wad funkcjonujących w polskim systemie podatkowym podatków dochodowych.

\section{Ewolucja opodatkowania dochodów osób prawnych}

Bezpośrednie opodatkowanie osób prawnych zmieniło się w pierwszym roku reformy podatkowej. W 1989 r. został wprowadzony podatek dochodowy od osób prawnych ${ }^{12}$, w którego konstrukcji zerwano z jedną z podstawowych zasad systemów podatkowych państw realnego socjalizmu, z zasadą nierówności sektorów własnościowych. Na wszystkie podmioty nałożono podatek wg jednolitej stawki wynoszącej 40\%. Należy jednak przypomnieć, że przedsiębiorstwa państwowe obciążone były również innymi świadczeniami (podatkiem

12 Ustawa z 31 stycznia 1989 r. o podatku dochodowym od osób prawnych, Dz.U. nr 3, poz. 12 , ze zm. 
od ponadnormatywnego wzrostu wynagrodzeń, obowiązkową dywidendą). Ustawa z 1989 r. funkcjonowała trzy lata, a w ciągu tego okresu dokonano trzykrotnej nowelizacji (m.in. ograniczano zakres ulg podatkowych, zaostrzono opodatkowanie ponadnormatywnego wzrostu wynagrodzeń). Od stycznia 1992 r. obowiązuje nowa ustawa o podatku dochodowym od osób prawnych, a przeprowadzone $\mathrm{w}$ niej zmiany były następstwem reformy systemu opodatkowania dochodów osób fizycznych. CIT obejmuje swoim zasięgiem przedsiębiorstwa (od mikroprzedsiębiorstw do dużych przedsiębiorstw), banki oraz inne instytucje finansowe. Niemożliwe jest dokonanie precyzyjnego uszeregowania zmian, które zaszły w konstrukcji tej daniny w tak długim okresie, ponieważ dotyczyły one różnych elementów konstrukcyjnych. Dlatego też poniżej została przedstawiona charakterystyka najważniejszych zmian kategorii z punktu widzenia ekonomicznej treści podatku.

Pewnej zmianie ulegał zakres podmiotowy (rozszerzony m.in. o spółki komandytowo-akcyjne, podatkowe grupy kapitałowe) oraz przedmiotowy podatku (m.in. przychody wcześniej zwolnione z podatku podlegają opodatkowaniu; zmiany w katalogu wydatków, które przez ustawodawcę nie są uznawane za koszty uzyskania przychodów).

Przedmiotem opodatkowania jest dochód, będący funkcją uzyskanych przychodów i poniesionych kosztów. Jeżeli jednak przychody są niższe od kosztów - powstaje strata. W razie wystąpienia straty podatnicy mają możliwość jej pokrycia z dochodu następnych lat podatkowych (przerzucanie straty w przód). Warto podkreślić, że ten element konstrukcji podatków dochodowych umożliwiający podatnikom dzielenie ryzyka rozwojowego $\mathrm{z}$ budżetem państwa zmieniono na ich korzyść. W latach 90 . poniesioną stratę pokrywano $\mathrm{w}$ równych częściach $\mathrm{z}$ dochodu uzyskanego w najbliższych, kolejno po sobie następujących trzech latach podatkowych. Od 20 lat podatnicy mogą dochód podatkowy obniżyć o wysokość straty w najbliższych, kolejno po sobie następujących pięciu latach podatkowych, po roku poniesienia straty. Podatnik sam dokonuje wyboru okresu rozliczenia straty podatkowej, z tym że wysokość obniżenia dochodu nie może przekroczyć w którymkolwiek z tych lat 50\% kwoty poniesionej straty.

Innym przykładem ograniczenia ryzyka decyzji rozwojowych za pomocą niektórych elementów konstrukcji podatku dochodowego jest możliwość stosowania w określonych warunkach amortyzacji przyspieszonej. Ustawodawca wprowadzał wiele korzystnych zmian pozwalających na stosowanie przez podatników strategii kosztowej (np. zaliczenie jednorazowo do kosztów uzyskania przychodów wydatków na zakup niektórych środków trwałych do wysokości wyznaczonego limitu; wprowadzenie indywidualnych stawek amortyzacyjnych). Instrumenty przyspieszonej amortyzacji powodują, ze względu na szybsze uznanie ceny nabycia (kosztów wytworzenia) za koszty uzyskania przychodów, tzw. efekt odroczenia opodatkowania. Dla podatników, przy tego 
rodzaju przesunięciu dochodu w czasie, oznacza to okresowe oszczędności podatkowe (podatkowy efekt odsetkowy).

Pisząc o kosztach uzyskania przychodów, nie można pominąć faktu, że dla obliczenia podstawy opodatkowania charakterystyczna jest ich negatywna selekcja, polegająca na enumeratywnym wyliczeniu kosztów, których nie można zaliczyć do kosztów uzyskania przychodów. Lista ta jest bardzo długa, obecnie liczy ponad 70 pozycji (w 1992 r. było zaledwie 19 pozycji). Ustawodawca przez zmiany tego elementu konstrukcyjnego próbował uszczelnić przepisy, uniemożliwiając tym samym podatnikom maksymalizację ich kosztów uzyskania przychodów. Nie ma wątpliwości, że to słaba strona konstrukcji podatku, powodująca wiele sporów, nieporozumień między podatnikiem a organami podatkowymi.

W polityce podatkowej państwa pewne znaczenie mogą mieć preferencje, głównie w postaci ulg podatkowych. Analizując funkcjonowanie CIT, można wskazać okresy, kiedy zgodnie z liberalnym rozumieniem zasady neutralności podatkowej ograniczano zakres ulg (lata 1990-1992, lata dwutysięczne) oraz okresy, kiedy wykorzystywano je jako narzędzie realizacji polityki gospodarczej kraju (lata 1993-1999). Upowszechnienie ulg w 1994 r. oznaczało ponowną zmianę filozofii podatkowej; zasada neutralności podatków - co podkreślała I. Bolkowiak - przestała być rozumiana jako odcięcie systemu podatkowego od wpływu na decyzje gospodarcze, a jej interpretacja nabrała mniej liberalnego charakteru i sprowadzała ją do obowiązku przestrzegania równości warunków opodatkowania wszystkich podmiotów, co miało w zasadniczy sposób kształtować ich pozycję konkurencyjną na rynku ${ }^{13}$. Wśród ulg szczególne znaczenie miały ulgi inwestycyjne: o powszechnym charakterze oraz z tytułu inwestycji w gminach zagrożonych wysokim bezrobociem strukturalnym. Z badań wynika jednak, że nie przyniosły one oczekiwanego rezultatu (tzn. zakładanego wzrostu wpływów budżetowych, mobilizacji kapitału inwestycyjnego, tworzenia nowych miejsc pracy, zwiększenia potencjału wytwórczego, szybszego postępu technicznego), ze względu m.in. na nieprecyzyjne przepisy, ryzyko błędnej interpretacji i w konsekwencji sankcje w przypadku wystąpienia zaległości podatkowych, ograniczenie możliwości korzystania $\mathrm{z}$ nich do nielicznych podmiotów, które na ogół posiadały środki na realizację inwesty$\mathrm{cji}^{14}$. W ostatnich latach $\mathrm{w}$ podatkach dochodowych ponownie pojawily się instrumenty wsparcia inwestycyjnego, najpierw w latach 2006-2015 ulga z tytułu nabycia nowych technologii oraz od 2016 r. ulga na działalność badawczo-rozwojową. Ta pierwsza stanowiła zachętę do nabywania i wdrażania nowych

13 I. Bolkowiak, System podatkowy a polityka społeczno-gospodarcza w latach 19891993, Instytut Finansów, Warszawa 1994, s. 35.

${ }^{14}$ Szczegółową analizę problemu zob. m.in. w: P. Felis, Funkcjonowanie ulg inwestycyjnych w podatku dochodowym od osób prawnych w latach 1994-1999 - próba oceny, seria „Studia i Prace Kolegium Zarządzania i Finansów”, z. 25, Warszawa 2002. 
technologii, a także zwiększała efekt działania nieodsetkowych tarcz podatkowych $^{15}$. Niestety i ta ulga okazała się instrumentem nieskutecznym, cechującym się niewielkim zainteresowaniem podatników. Przyczyny były podobne do tych, które dotyczyły funkcjonujących wcześniej ulg inwestycyjnych, czyli: mankamenty konstrukcji ulgi, liczne wątpliwości interpretacyjne przepisów oraz obawy podatników przed kwestionowaniem ich podejścia przez organy podatkowe ${ }^{16}$. Druga ulga premiuje podmioty realizujące prace badawczo-rozwojowe. Umożliwia odliczenie od podstawy opodatkowania części wydatków (tzw. kosztów kwalifikowanych) niezależnie od tego, czy wpłynęły już na nią jako koszty uzyskania przychodów.

Podatnicy mogli także przez pewien czas skorzystać z innych odliczeń, np. z tytułu obniżenia opłaty eksploatacyjnej za wydobywanie kopalin (do 2002 r.), wydatków na budownictwo mieszkaniowe w celu wynajmowania (do 1997 r.). Spośród kilku rodzajów odliczeń od dochodu utrzymano jedynie darowizny, choć zmieniały się szczegółowe zasady (np. limit odliczeń - obecnie do 10\% dochodu). W katalogu podatkowych instrumentów służących wspieraniu rozwoju przedsiębiorczości można także wskazać instytucję kredytu podatkowego, w celu odroczenia zapłaty zobowiązań podatkowych. Sama idea rozwiązania zasługuje na aprobatę, w praktyce jednak nadmierny rygoryzm prawny skutecznie zablokował korzystanie z pomocy, niwecząc tym samym przyjęty cel wsparcia fiskalnego przedsiębiorcó $w^{17}$.

Podstawowa stawka podatkowa do 1996 r. wynosiła 40\%, później była stopniowo obniżana, aż do obecnych 19\% (od 2004 r.). Od 2017 r. niektórzy podatnicy CIT (mali podatnicy oraz ci, którzy rozpoczynają działalność) mogą się rozliczać wg preferencyjnej stawki w wysokości $15 \%$.

Podatnicy podatku są obowiązani do samoobliczania zarówno należnych zaliczek na podatek, jak i samego podatku. Od początku obowiązywania podatku przedsiębiorcy wpłacali zaliczki miesięczne w wysokości różnicy między podatkiem należnym od dochodu osiągniętego od początku roku podatkowe-

15 Piszą o tym m.in. P Felis, Wybrane rozwiązania opodatkowania matych przedsiębiorstw - ocena i proponowane kierunki zmian, „Studia BAS” 2014, nr 1(37), s. 132 (Rozwój przedsiębiorczości oraz sektora małych i średnich przedsiębiorstw, red. G. Gołębiowski); M. Jamroży, Podatkowe zachęty inwestycyjne dla przedsiębiorców [w:] Finanse - nowe wyzwania teorii i praktyki. Finanse przedsiębiorstw, red. S. Wrzosek, Wydawnictwo Uniwersytetu Ekonomicznego we Wrocławiu, Wrocław 2011, s. 580, https://doi. org/10.17951/h.2016.50.1.529.

${ }_{16}$ Zob. m.in. w: N. Kotlarek, Ulga z tytułu nabycia nowych technologii - mankamenty konstrukcji i propozycje modyfikacji, „Annales Universitatis Mariae Curie-Skłodowska, sectio H (Oeconomia)", 2016, Vol. 50, No 1.

17 Zob. P. Felis, Wybrane rozwiązania opodatkowania matych przedsiębiorców - ocena i proponowane kierunki zmian, op. cit., s. 129-131; M. Jamroży, Podatkowe zachęty inwestycyjne dla przedsiębiorców, op. cit., s. 580. 
go a sumą zaliczek należnych za poprzednie miesiące. Zaliczki powinny być wpłacone do 20 dnia każdego miesiąca za miesiąc poprzedni. Od 2012 r. za ostatni miesiąc roku podatkowego podatnik wpłaca zaliczkę $\mathrm{w}$ terminie do 20 dnia miesiąca następnego roku podatkowego ${ }^{18}$. Zmiana ta była korzystna chociażby z punktu widzenia płynności finansowej, ponieważ wcześniej zaliczkę na podatek za ostatni miesiąc podatnik musiał zapłacić do 20 dnia tego miesiąca, czyli w terminie i wysokości podatku za poprzedni miesiąc ${ }^{19}$. Mali podatnicy oraz rozpoczynający działalność mogą wpłacać zaliczki na podatek kwartalnie. Od 2003 r. obowiązuje także korzystna dla części podatników uproszczona formuła wpłaty zaliczek. Warto dodać, że uproszczono również zasady ostatecznego rozliczenia podatku. Wcześniej podatnicy byli zobowiązani do złożenia wstępnego zeznania podatkowego (do końca trzeciego miesiąca roku następnego) oraz zeznania o ostatecznej wysokości dochodu (w terminie 10 dni od daty zatwierdzenia rocznego sprawozdania, lecz nie później niż przed upływem 9 miesięcy od zakończenia roku podatkowego). Obecnie, niezależnie od metody wpłaty zaliczek wszyscy podatnicy są obowiązani do złożenia rocznego zeznania podatkowego do końca trzeciego miesiąca danego roku za rok poprzedni (ponieważ w zasadzie rokiem podatkowym jest rok kalendarzowy - do końca marca).

Na zakończenie tej części artykułu należy stwierdzić, że od początku obowiązywania CIT corocznie dokonywano zmian w jego konstrukcji. Dotyczyły one większości elementów konstrukcyjnych, przede wszystkim zakresu przedmiotowego, kosztów uzyskania przychodów, odliczeń od dochodu, wysokości stawki podatkowej. Niektóre zmiany były dla podatników korzystne, np. obniżanie stawki podatkowej, a także instrumenty podatkowe o charakterze stymulacyjnym. W większości - co zostanie wykazane w dalszej części artykułu były to zmiany, które spowodowały nie tylko wzrost dochodów budżetowych, ale miały - co ważne dla przedsiębiorców - wpływ na wysokość obciążeń podatkowych, a w konsekwencji na ich sytuację finansową.

\section{Ewolucja opodatkowania dochodów osobistych}

Od 1992 r. na mocy ustawy o podatku dochodowym od osób fizycznych zasadniczym zmianom uległy zasady opodatkowania ludności. Wprowadzono wówczas na wzór wielu krajów - powszechny podatek dochodowy od osób fizycznych. Oznaczało to jednocześnie likwidację wielu podatków, charakterystycznych dla poprzedniego ustroju, kiedy to opodatkowanie dochodów było zróżnicowane w zależności od źródeł ich uzyskania (podatku od wynagrodzeń,

18 Zakładając, że rokiem podatkowym jest rok kalendarzowy, to zaliczkę należy wpłacać do 20 stycznia roku następnego.

19 Zaliczkę za grudzień wpłacano w podwójnej wysokości przypadającej za listopad. 
podatku od płac, podatku wyrównawczego, podatku dochodowego, części podatku rolnego dotyczącej dochodów z działów specjalnych produkcji rolnej).

Podatnikami są osoby fizyczne, które uzyskują dochody z różnych źródeł przychodów objętych tym podatkiem, takich jak np.: wynagrodzenie za pracę, w ramach stosunku pracy; przychody z działalności wykonywanej osobiście (m.in. działalności artystycznej, naukowej, publicystycznej, wykonywania usług na podstawie umowy-zlecenia lub umowy o dzieło); przychody z działalności gospodarczej prowadzonej na własny rachunek (także w formie spółki niemającej osobowości prawnej); z działów specjalnych produkcji rolnej oraz z praw majątkowych. Co ciekawe, w tytule źródeł przychodów ustawodawca wskazał także inne źródła, co sprawia, że katalog nie jest zamknięty. Podatnik nie ma zatem możliwości uniknięcia opodatkowania dochodu ze względu na brak specyfikacji źródeł przychodów. Czynnikiem wpływającym na zakres podmiotowości podatkowej jest od 2003 r. miejsce zamieszkania podatnika. Wcześniej nieograniczonemu obowiązkowi podatkowemu podlegały osoby mające miejsce zamieszkania w Polsce oraz przebywające na jej terytorium w roku podatkowym dłużej niż 183 dni. W PIT przyjęto od samego początku zasadę, że małżonkowie podlegają odrębnemu opodatkowaniu z tytułu osiąganych dochodów. Ustawodawca wprowadził jednak wyjątek od tej zasady i dopuścił od 1992 r. możliwość wspólnego opodatkowania małżonków (od 1993 r. także osobom samotnie wychowującym dzieci przyznano prawo do łącznego opodatkowania się wraz z dziećmi) - prorodzinnej preferencji. Skorzystanie z prawa wspólnego opodatkowania dochodów małżonków jest możliwe po łącznym spełnieniu pewnych warunków, np. istnienie między nimi wspólnoty majątkowej, pozostawanie w związku małżeńskim cały rok podatkowy. Od 2005 r. warunki nieco złagodzono, co było korzystne z punktu widzenia interesów rodziny, możliwa jest także sytuacja, gdy wniosek został złożony przez podatnika, który zawarł małżeństwo przed rozpoczęciem roku podatkowego, a jego małżonek zmarł w trakcie roku podatkowego. Dotyczy to także podatnika, którego małżonek zmarł przed złożeniem zeznania podatkowego.

Przedmiotem opodatkowania są różne rodzaje dochodów, w kilku sytuacjach przedmiotem opodatkowania jest zaś przychód. Jeśli podatnik uzyskuje dochody z kilku źródeł, przedmiotem opodatkowania jest suma dochodów ze wszystkich tych źródeł, w przypadku których możliwe jest łączne opodatkowanie. Charakterystyczne dla PIT jest uzależnienie sposobu ustalania kosztów uzyskania przychodów od źródła przychodów. Ich poziom jest bardzo zróżnicowany, a znaczenie ma nie tyle koszt w sensie ekonomicznym, rachunkowym, co w sensie prawnym - uznany przez ustawodawcę za możliwy do odliczenia. W przypadku podatników uzyskujących przychody z prowadzenia działalności gospodarczej przyjęto takie same zasady, jak wobec przedsiębiorstw opodatkowanych CIT. Są to więc koszty poniesione w celu osiągnięcia przychodów (od 2007 r. także w celu zachowania albo zabezpieczenia źródła przychodów), 
$\mathrm{z}$ wyjątkiem kosztów enumeratywnie wymienionych w ustawie. Natomiast podatnicy uzyskujący przychody z działalności wykonywanej osobiście, ze stosunku pracy oraz niektórych pozostałych źródeł przychodów odliczają od przychodów koszty uzyskania do wysokości limitów (kwotowych lub procentowych). Rozwiązanie polegające na kumulacji dochodów z różnych źródeł przychodów, w celu ustalenia dochodu do opodatkowania podatnika sprawia, że PIT zaliczany jest do podatków globalnych (syntetycznych). Można jednak, ze względu na wspomniane różnice w sposobie określania kosztów podatkowych, znacznej rozpiętości w ich wysokości, a nawet braku związku z charakterem uzyskiwanego przychodu i jego wysokością, doszukać się w tym podatku cech podatku cedularnego ${ }^{20}$.

W konstrukcji podatku zawarto wiele odliczeń od dochodu (ulg pośrednich), które ulegały w analizowanym okresie dużym zmianom. Dla podatników najkorzystniejszy był okres do 1998 r., wówczas przysługiwało im najwięcej tytułów odliczeń od dochodu, m.in. darowizny (przez pewien czas także na rzecz osób fizycznych); wydatki mieszkaniowe; wydatki na budowę mieszkań na wynajem; wydatki na cele rehabilitacyjne; wydatki na zakup przyrządów i pomocy naukowych; wydatki na dokształcanie i doskonalenie zawodowe podatnika; składki na rzecz organizacji, do których przynależność podatnika jest obowiązkowa; wydatki na dojazd dzieci do szkół; wydatki na odpłatne kształcenie dzieci w szkołach; wydatki na zakup obligacji Skarbu Państwa; renty; wydatki inwestycyjne dla przedsiębiorców. Były to więc ulgi związane z egzystencją podatnika i jego rodziny, ulgi o charakterze szkoleniowym oraz stymulacyjnym (ok. 15 tytułów odliczeń). W latach dwutysięcznych podatnikom przysługiwało już mniej odliczeń od dochodu (w poszczególnych latach było to od 5 do 10 tytułów). Nowymi preferencjami były m.in. ulga odsetkowa (odliczeniu podlegały wydatki poniesione na spłatę odsetek od kredytu/pożyczki, udzielonych podatnikowi na sfinansowanie inwestycji mającej na celu zaspokojenie własnych potrzeb mieszkaniowych); ulga internetowa (wydatki z tytułu użytkowania internetu); ulga inwestycyjna na nabycie nowych technologii. Obecnie podatnicy, pomijając prawa nabyte, mogą dokonać jedynie następujących odliczeń od dochodu: z tytułu strat z lat ubiegłych (podatnicy osiągający dochody z działalności gospodarczej z działów specjalnych produkcji rolnej, prowadzący księgi podatkowe); składki na ubezpieczenia społeczne; wpłaty na indywidualne konto zabezpieczenia emerytalnego; wydatki na cele rehabilitacyjne (szeroki katalog wydatków rehabilitacyjnych, związany z ułatwieniem wykonywania przez osoby niepełnosprawne czynności życiowych, niewielki zakres stosowanych limitów dopuszczalnych kwot niektórych odliczeń); wydatki ponoszone przez podatnika $\mathrm{z}$ tytułu użytkowania internetu

20 E. Małecka-Ziembińska, Efektywność fiskalna podatku dochodowego od osób fizycznych w Polsce, Wydawnictwo Uniwersytetu Ekonomicznego w Poznaniu, Poznań 2012, s. 132. 
(do wysokości 760 zł, od 2013 r. ograniczenie - podatnicy mogą teraz tylko przez dwa lata odliczać udokumentowane wydatki z tym związane); darowizny (maksymalnie do 6\% dochodu, przekazane organizacjom pożytku publicznego, na cele kultu religijnego, na cele krwiodawstwa realizowanego przez honorowych dawców krwi w wysokości ekwiwalentu pieniężnego za pobraną krew); ulga inwestycyjna na badania i rozwój.

Podobnie jak w przypadku ulg odliczanych od dochodu również katalog ulg odliczanych od podatku (ulgi bezpośrednie) był poddawany dużym zmianom. Początkowo nie odgrywały one większej roli, pomijając uwzględnioną w taryfie opodatkowania ustawową kwotę obniżki podatku, była to wyłącznie dla prowadzących działalność gospodarczą ulga za kształcenie uczniów odbywających praktyki u przedsiębiorców oraz za przyuczenie do zawodu osób bezrobotnych (tzw. ulga uczniowska, która funkcjonowała do końca 2003 r.). Później sytuacja się zmieniła, kiedy od 1997 r. przekwalifikowano część ulg pośrednich na bezpośrednie (m.in. ulgę mieszkaniową, ulgę remontową, z tytułu dojazdu dzieci do szkół, czesne za kształcenie dzieci w szkołach, za nabycie pomocy naukowych, za kształcenie w szkołach wyższych, za dokształcanie zawodowe podatnika). Nową ulgą była ulga zdrowotna, zlikwidowana jednak dosyć szybko, bo z końcem 2001 r. Przy wymienionych ulgach obowiązywały maksymalne limity jako podstawy do ustalenia kwoty obniżenia podatku, przy zastosowaniu stawki 19\%. Z końcem 2003 r. zlikwidowano większą część pozostałych ulg odliczanych od podatku. Obecnie podatnicy mogą skorzystać z dwóch tytułów: zapłaconych składek na powszechne ubezpieczenia zdrowotne (kwota składki, o którą zmniejsza się podatek, nie może jednak przekroczyć 7,75\% podstawy wymiaru tej składki) oraz z tytułu wychowywania dzieci. Ulga na dzieci została wprowadzona w 2007 r., i od tego czasu wprowadzono kilka zmian (sposób ustalania kwoty ulgi, zakres podmiotowy). Początkowe regulacje pozwalały przede wszystkim na zwiększenie dochodu rodzin średnio i wysoko zamożnych. Celem tego typu instrumentów powinna być jednak poprawa redystrybucji dochodów, co jest szczególnie istotne dla osób o niskich dochodach (ograniczenie ubóstwa materialnego wśród dzieci). Zmiany formuły ulgi prorodzinnej w $2014 \mathrm{r}$. umożliwiły w praktyce wsparcie podatników o niskich dochodach, mających na utrzymaniu więcej dzieci. W literaturze analizującej skuteczność tego typu preferencji pojawiają się jednak głosy, że nie były to zmiany wystarczające dla wspierania rodzin wielodzietnych o niskich dochodach ${ }^{21}$. Podsumowując, zmiany w zakresie ulg odliczanych zarówno od dochodu przed opodatkowaniem, jak i od podatku wskazują jednoznacznie tendencję ich ograniczania ${ }^{22}$.

${ }^{21}$ Zob. np. w: R. Budlewska, Ulga na dzieci jako instrument realizacji polityki prorodzinnej w Polsce, „Annales Universitatis Mariae Curie-Skłodowska, sectio H (Oeconomia)”, 2016, Vol. 50, No 1, https://doi.org/10.17951/h.2016.50.1.725.

22 Szczegółowa analiza tematu m.in. w: J. Ickiewicz, Obciążenia fiskalne przedsiębiorstw, PWE, Warszawa 2009; E. Małecka-Ziembińska, Efektywność fiskalna podatku dochodowego 
W podatku dochodowym obciążającym osoby fizyczne skala ma charakter progresji szczeblowanej, a szczegóły przedstawiające jej kształt w latach 1992-2016 pokazano w tabeli 1. Od momentu wprowadzenia PIT zastosowanie znalazła skala progresji ciągłej z trzema progami podatkowymi, dopiero od 2009 r. liczba progów zmalała do dwóch. Najwyższe stawki obowiązywały w latach 1994-1996. W 1997 r. obniżono je o jeden punkt procentowy dla poszczególnych przedziałów dochodów, a następnie przyjęte w 1998 r. stawki obowiązywały do końca 2008 r. Istotna zmiana nastąpiła od 2009 r., od tego momentu obowiązują dwa przedziały skali i stawki $18 \%$ oraz $32 \%$. Zmieniała się także kwota tzw. ustawowej obniżki podatku, która wpływała na wysokość kwoty wolnej od podatku. Niekorzystne dla podatników było m.in. zamrożenie w 2001 r. oraz w 2009 r. progów podatkowych, a także brak waloryzacji w latach 2003-2006, 2009-2016 kwoty dochodu wolnej od opodatkowania. Wymienione działania powodowały wzrost ciężarów podatkowych dla poszczególnych grup podatników.

Od 2004 r. osobom fizycznym osiągającym dochody z pozarolniczej działalności gospodarczej, a od 2007 r. również z działów specjalnych produkcji rolnej, przysługuje prawo ich opodatkowania wg stałej stawki 19\%. Wybór takiego sposobu opodatkowania wiąże się jednak z rezygnacją z odliczeń większości ulg, w tym również tych, do których prawa zostały nabyte w latach wcześniejszych. Podatnicy zachowują jedynie prawo do odliczenia od dochodu przed opodatkowaniem składek ubezpieczenia społecznego, wpłat na indywidualne konto zabezpieczenia emerytalnego (IKZE) oraz strat $\mathrm{z}$ lat ubiegłych, a od podatku - składki na powszechne ubezpieczenie zdrowotne. Podatnik może stracić $\mathrm{w}$ roku podatkowym możliwość takiego opodatkowania, jeśli uzyska z działalności gospodarczej - prowadzonej samodzielnie lub z tytułu prawa do udziału w zysku spółki niemającej osobowości prawnej przychody ze świadczenia usług na rzecz byłego lub obecnego pracodawcy, odpowiadających czynnościom, które on sam lub co najmniej jeden ze wspólników wykonywał lub wykonuje w roku podatkowym (do 2009 r. także w roku poprzedzającym rok podatkowy) - w ramach stosunku pracy lub spółdzielczego stosunku pracy.

Według stałej (19\%) stawki opodatkowuje się także inne dochody, których nie łączy się z pozostałymi dochodami i w odniesieniu do których nie przysługują podatnikom ulgi, np. dochody ze sprzedaży papierów wartościowych. W obecnym modelu opodatkowania dochodów rośnie także liczba tytułów dochodów (przychodów) opodatkowanych odrębnie wg stałej stawki zryczałtowanym podatkiem dochodowym. Niewątpliwie można to uznać za odstęp-

od osób fizycznych w Polsce, op. cit.; A. Ślesicka, Stosowanie ulg i zwolnień w podatku dochodowym od osób fizycznych w państwach UE, „Studia BAS” 2008, nr 14, t. 1 (Tendencje w opodatkowaniu dochodów osób fizycznych w państwach UE, red. M. Korolewska). 
Tabela 1. Skale podatkowe w podatku dochodowym od osób fizycznych w latach 1992-2016*

\begin{tabular}{|c|c|c|c|c|}
\hline \multirow[t]{2}{*}{ Lata } & \multirow{2}{*}{$\begin{array}{l}\text { Kwota dochodu } \\
\text { wolna od podatku } \\
\qquad(w \mathrm{z} f)^{* *}\end{array}$} & \multicolumn{2}{|c|}{$\begin{array}{l}\text { Podstawa obliczenia } \\
\text { podatku (w zł) }\end{array}$} & \multirow[t]{2}{*}{ Wysokość podatku } \\
\hline & & ponad & do & \\
\hline 1992-1993 & 432 & $\begin{array}{r}6480 \\
12960 \\
\end{array}$ & $\begin{array}{r}6480 \\
12960\end{array}$ & $\begin{array}{l}20 \% \text { podstawy obliczenia minus kwota } 86,40 \text { zł } \\
1209,60+30 \% \text { nadwyżki ponad } 6480 \mathrm{zł} \\
3153,60+40 \% \text { nadwyżki ponad } 12960 \text { zł }\end{array}$ \\
\hline 1994 & 577 & $\begin{array}{r}9080 \\
18160\end{array}$ & $\begin{array}{r}9080 \\
18160\end{array}$ & $\begin{array}{l}21 \% \text { podstawy obliczenia minus kwota } 121,20 \text { zł } \\
1785,60+33 \% \text { nadwyżki ponad } 9080 \text { zł } \\
4782+45 \% \text { nadwyżki ponad } 18160 \text { zł }\end{array}$ \\
\hline 1995 & 789 & $\begin{array}{l}12400 \\
24800\end{array}$ & $\begin{array}{l}12400 \\
24800\end{array}$ & $\begin{array}{l}21 \% \text { podstawy obliczenia minus kwota } 165,60 \mathrm{zł} \\
2438,40+33 \% \text { nadwyżki ponad } 12400 \mathrm{zł} \\
6530,40+45 \% \text { nadwyżki ponad } 24800 \mathrm{zł}\end{array}$ \\
\hline 1996 & 1040 & $\begin{array}{l}16380 \\
32760 \\
\end{array}$ & $\begin{array}{l}16380 \\
32760\end{array}$ & $\begin{array}{l}21 \% \text { podstawy obliczenia minus kwota } 218,40 \mathrm{zł} \\
3221,40+33 \% \text { nadwyżki ponad } 16380 \mathrm{zł} \\
8626,80+45 \% \text { nadwyżki ponad } 32760 \mathrm{zł}\end{array}$ \\
\hline 1997 & 1391 & $\begin{array}{l}20868 \\
41736 \\
\end{array}$ & $\begin{array}{l}20868 \\
41736\end{array}$ & $\begin{array}{l}20 \% \text { podstawy obliczenia minus kwota } 278,20 \mathrm{zł} \\
3895,40+32 \% \text { nadwyżki ponad } 20868 \mathrm{zł} \\
10573,16+44 \% \text { nadwyżki ponad } 41736 \mathrm{zł}\end{array}$ \\
\hline 1998 & 1772 & $\begin{array}{l}25252 \\
50504\end{array}$ & $\begin{array}{l}25252 \\
50504\end{array}$ & $\begin{array}{l}\text { 19\% podstawy obliczenia minus kwota } 336,60 \text { zł } \\
4461,28+30 \% \text { nadwyżki ponad } 25252 \mathrm{zł} \\
12036,88+40 \% \text { nadwyżki ponad } 50504 \mathrm{zł}\end{array}$ \\
\hline 1999 & 2078 & $\begin{array}{l}29624 \\
59248\end{array}$ & $\begin{array}{l}29624 \\
59248\end{array}$ & $\begin{array}{l}19 \% \text { podstawy obliczenia minus kwota } 394,80 \text { zł } \\
5233,76+30 \% \text { nadwyżki ponad } 29624 \text { zł } \\
14120,96+40 \% \text { nadwyżki ponad } 59248 \text { zł }\end{array}$ \\
\hline 2000 & 2296 & $\begin{array}{l}32736 \\
65472\end{array}$ & $\begin{array}{l}32736 \\
65472\end{array}$ & $\begin{array}{l}19 \% \text { podstawy obliczenia minus kwota } 436,20 \text { zł } \\
5783,64+30 \% \text { nadwyżki ponad } 32736 \text { zł } \\
15604,44+40 \% \text { nadwyżki ponad } 65472 \text { zł }\end{array}$ \\
\hline 2001 & 2596 & $\begin{array}{l}37024 \\
74048 \\
\end{array}$ & $\begin{array}{l}37024 \\
74048\end{array}$ & $\begin{array}{l}19 \% \text { podstawy obliczenia minus kwota } 493,32 \text { zł } \\
6541,24+30 \% \text { nadwyżki ponad } 37024 \text { zł } \\
17648,44+40 \% \text { nadwyżki ponad } 74048 \text { zł }\end{array}$ \\
\hline 2002 & 2727 & $\begin{array}{l}37024 \\
74048\end{array}$ & $\begin{array}{l}37024 \\
74048\end{array}$ & $\begin{array}{l}19 \% \text { podstawy obliczenia minus kwota } 518,16 \text { zł } \\
6516,40+30 \% \text { nadwyżki ponad } 37024 \text { zł } \\
17623,60+40 \% \text { nadwyżki ponad } 74048 z \nmid\end{array}$ \\
\hline 2003-2006 & 2790 & $\begin{array}{l}37024 \\
74048\end{array}$ & $\begin{array}{l}37024 \\
74048\end{array}$ & $\begin{array}{l}19 \% \text { podstawy obliczenia minus kwota } 530,08 \text { zł } \\
6504,48+30 \% \text { nadwyżki ponad } 37024 \text { zł } \\
17611,68 z \nmid+40 \% \text { nadwyżki ponad } 74048 \text { zł }\end{array}$ \\
\hline 2007 & 3013 & $\begin{array}{l}43405 \\
85528\end{array}$ & $\begin{array}{l}43405 \\
85528\end{array}$ & $\begin{array}{l}19 \% \text { podstawy obliczenia minus kwota } 572,54 \text { zł } \\
7674,41 z \nmid+30 \% \text { nadwyżki ponad } 43405 \text { zł } \\
20311,31+40 \% \text { nadwyżki ponad } 85528 \text { zł }\end{array}$ \\
\hline 2008 & 3089 & $\begin{array}{l}44490 \\
85528\end{array}$ & $\begin{array}{l}44490 \\
85528\end{array}$ & $\begin{array}{l}19 \% \text { podstawy obliczenia minus kwota } 586,85 \text { zł } \\
7866,25+30 \% \text { nadwyżki ponad } 44490 \mathrm{zł} \\
20177,65+40 \% \text { nadwyżki ponad } 85528 \text { zł }\end{array}$ \\
\hline 2009-2016 & 3089 & 85528 & 85528 & $\begin{array}{l}18 \% \text { podstawy obliczenia minus kwota } 556,02 \text { zł } \\
14839,02+32 \% \text { nadwyżki ponad } 85528 \text { zł }\end{array}$ \\
\hline
\end{tabular}

* Dla kwot z lat 1992-1994 uwzględniono przeprowadzony od 1995 r. proces denominacji złotego.

** W zaokrągleniu do pełnych złotych.

Źródło: na podstawie art. 27 ust. 1 ustawy o podatku dochodowym od osób fizycznych. 
stwo od zasady opodatkowania dochodu globalnego (syntetycznego) na rzecz opodatkowania zdeterminowanego przez źródła uzyskania przychodu ${ }^{23}$. Niektórzy autorzy oceniają to negatywnie, wskazując na wątpliwości, w związku ze zmieniającą się dynamicznie rzeczywistością społeczno-gospodarczą, dotyczące zachowanego przez ustawodawcę $\mathrm{z}$ poprzedniego systemu podziału na źródła przychodów. Zdaniem J. Kulickiego podział ten utrwala mechanizmy ustalania i opodatkowania dochodów obowiązujące w podatku od wynagrodzeń, podatku od płac, podatku wyrównawczym czy też podatku dochodowym w kształcie sprzed $1992 \mathrm{r}^{24}$.

W PIT zasady obliczania zaliczek są zróżnicowane w zależności od źródła i podstawy prawnej osiąganego dochodu. Jeśli chodzi o dochody ze stosunku pracy, to zaliczki pobierane są przez zakłady pracy, a wyższa stawka progresywnej skali podatkowej ma zastosowanie od miesiąca następującego po miesiącu, w którym dochody podatnika, liczone narastająco od początku roku, przekroczyły kolejny przedział skali. Z kolei podatnicy osiągający dochody z działalności gospodarczej obliczają i wpłacają zaliczki samodzielnie. Od 2003 r. mają możliwość wyboru: na podstawie wysokości osiągniętego dochodu lub wg formy uproszczonej. Począwszy od 2007 r. podatnicy osiągający dochody z działalności gospodarczej, mający status małych podatników lub rozpoczynający prowadzenie działalności gospodarczej, mogą wpłacać zaliczki kwartalne. Natomiast termin złożenia zeznania rocznego jest jednakowy dla wszystkich podatników, bez względu na sposób obliczania zaliczek - zeznanie należy złożyć do 30 kwietnia roku następującego po roku podatkowym.

$\mathrm{W}$ ustawie o podatku dochodowym wprowadzano bardzo dużo zmian, mających na celu przede wszystkim usprawnienie poboru podatku, ograniczenie nieprawidłowości w jego wymiarze. Na ogół są postrzegane jako zmiany stanowiące wyraz dbałości o interes fiskalny państwa. W początkowym okresie funkcjonowania PIT stosowano szerokie spektrum preferencji podatkowych, powodujących zmniejszenie wymiaru podatku. Później widoczna była tendencja do zmniejszania liczby ulg, co oznaczało odchodzenie od pełnienia przez podatek dochodowy funkcji pozafiskalnych. W ostatnich latach ponownie można zaobserwować wzmocnienie jego prorodzinnego (ulga na dzieci) oraz inwestycyjnego (ulga na prace badawczo-rozwojowe) charakteru. Ważne, co zostanie zbadane w dalszej części artykułu, jak to zaważyło na funkcji fiskalnej oraz osiągnięciu celów gospodarczych i społecznych.

${ }^{23}$ Więcej na temat zob. E. Małecka-Ziembińska, Efektywność fiskalna podatku dochodowego, op. cit., s. 156.

24 J. Kulicki, Reforma opodatkowania dochodów, op. cit. s. 346. 


\section{Znaczenie fiskalne podatków dochodowych w latach 2003-2016}

Podstawowym źródłem dochodów budżetowych są podatki. W tabeli 2 zaprezentowano wpływy budżetowe z podatków i ceł, ze szczególnym uwzględnieniem podatków dochodowych. W przypadku podatków dochodowych są to wartości bez odliczenia udziałów dla jednostek samorządu terytorialnego, co pozwala na bardziej wiarygodną ocenę ich fiskalnego znaczenia. Pomijamy więc wpływ zmian systemowych, związanych z przesunięciem części wpływów z tych podatków do innych segmentów sektora finansów publicznych. Nie zmienia to faktu, że największe znaczenie mają wpływy z podatku od towarów i usług (VAT), ale po nim plasują się wpływy z PIT. W analizowanym okresie wpływy z PIT stanowiły przeciętnie $25,1 \%$ wszystkich wpływów podatkowych. Znaczenie drugiego z podatków dochodowych, CIT, jest zdecydowanie mniejsze, przeciętnie 11,4\% ogółu wpływów. Można także odnotować, że wraz z upływem czasu zmniejszała się dysproporcja między podatkami dochodowymi a pośrednimi. W 2003 r. podatki dochodowe stanowily 34,4\% wpływów podatkowych, natomiast w 2016 r. już 38,1\%. To pozytywne zjawisko w kontekście możliwości wykorzystania podatków dochodowych (przede wszystkim PIT) w ograniczaniu nierówności dochodowych w społeczeństwie i w sprawiedliwym rozłożeniu ciężarów podatkowych. S. Owsiak pisze, że: podatki pośrednie sa anonimowe i sa płacone w oderwaniu od sytuacji dochodowej i rodzinnej podatnika ${ }^{25}$.

W analizowanych latach 2003-2016 wszystkie zamieszczone w tabeli 2 tytuły podlegały wahaniom, co było rezultatem różnych czynników, wpływu koniunktury gospodarczej oraz zmian przeprowadzanych przez ustawodawcę. $\mathrm{W}$ początkowym okresie badawczym gospodarka znalazła się $\mathrm{w}$ fazie ożywienia gospodarczego, by później w następnych dwóch latach przejść w fazę rozkwitu. Kolejny okres (przede wszystkim 2009 r. oraz 2012-2013) to gospodarcze spowolnienie. Wrażliwość wpływów z podatków dochodowych (zwłaszcza CIT) na przebieg koniunktury gospodarczej oraz potencjał gospodarczy skutkowała więc ich wyraźnymi wahaniami - tendencją wzrostową $w$ fazie rozkwitu i spadkową w okresie recesji. Zważywszy jednak, że tempo zmian podstawowych zmiennych makroekonomicznych (PKB, popyt krajowy) na ogół odbiegało od tempa zmian wpływów z podatków dochodowych, także i przedstawione wcześniej niektóre elementy konstrukcji podatków dochodowych mogły sprzyjać pełnieniu funkcji fiskalnej. Duży wpływ należałoby przypisać zmianom dotyczącym poszerzenia bazy podatkowej (ograniczenie ulg i zwolnień podatkowych; powiększenie katalogu wydatków nieuznawanych za kosz-

25 S. Owsiak, System podatkowy Polski w okresie transformacji - próba oceny, „Annales Universitatis Mariae Curie-Skłodowska, sectio H (Oeconomia)” 2016, Vol. 50, No 1, s. 21, https://doi.org/10.17951/h.2016.50.1.15. 
Tabela 2. Wpływy budżetowe, z uwzględnieniem PIT i CIT (mln zł) oraz ich dynamika w latach 2003-2016

\begin{tabular}{|c|c|c|c|c|c|c|}
\hline \multirow{2}{*}{ Lata } & \multirow{2}{*}{ Ogółem } & \multirow{2}{*}{ PIT } & \multirow{2}{*}{ CIT } & \multicolumn{3}{|c|}{ Rok poprzedni $=100$} \\
\cline { 5 - 7 } & & & & Ogółem & PIT & CIT \\
\hline 2003 & 146632,95 & 35438,48 & 14982,38 & - & - & - \\
\hline 2004 & 158255,72 & 36667,43 & 18030,23 & 107,9 & 103,5 & 120,3 \\
\hline 2005 & 179919,61 & 42185,64 & 20789,23 & 113,7 & 115,0 & 115,3 \\
\hline 2006 & 202832,14 & 48690,55 & 25342,49 & 112,7 & 115,4 & 121,9 \\
\hline 2007 & 241358,69 & 60959,16 & 32165,46 & 119,0 & 125,2 & 126,9 \\
\hline 2008 & 257238,49 & 67193,53 & 34635,01 & 106,6 & 110,2 & 107,7 \\
\hline 2009 & 250101,11 & 62740,79 & 30774,32 & 97,2 & 93,4 & 88,9 \\
\hline 2010 & 257232,22 & 62487,00 & 27891,93 & 102,9 & 99,6 & 90,6 \\
\hline 2011 & 281442,32 & 67505,12 & 31739,30 & 109,4 & 108,0 & 113,8 \\
\hline 2012 & 286438,34 & 70621,94 & 31949,94 & 101,8 & 104,6 & 100,7 \\
\hline 2013 & 280521,85 & 73751,31 & 29379,65 & 97,9 & 104,4 & 92,0 \\
\hline 2014 & 297345,17 & 78127,39 & 29709,28 & 106,0 & 105,9 & 101,1 \\
\hline 2015 & 306230,06 & 83140,15 & 32894,16 & 103,0 & 106,4 & 110,7 \\
\hline 2016 & 323590,26 & 89340,15 & 33825,20 & 105,7 & 107,5 & 102,8 \\
\hline
\end{tabular}

Źródło: na podstawie Wpływy budżetowe za okres od 1 stycznia 2003 r. do 31 grudnia 2016 r., www.mf.gov.pl.

ty uzyskania przychodów). Na rozwinięcie zasługuje wykorzystanie dwóch różnych taryf w opodatkowaniu dochodów - skali proporcjonalnej (radykalna obniżka stawki CIT w 2004 r. z 27\% do 19\% podstawy opodatkowania oraz wprowadzenie fakultatywnie możliwości liniowego podatku od 2004 r. w takiej samej wysokości dla osób fizycznych prowadzących pozarolniczą działalność gospodarczą), a także skali progresywnej (różne skale i poziom progresywnego opodatkowania). W początkowym okresie mieliśmy do czynienia z ukrytym podwyższaniem podatków, nieusankcjonowanym prawnie (zjawisko tzw. zimnej progresji) ${ }^{26}$. Jak wynika $\mathrm{z}$ tabeli 1 granice progów podatkowych oraz kwota wolna od podatku do 2006 r. w ogóle nie zmieniły się. Dopiero od 2007 r. podniesiono wartości graniczne poszczególnych progów, co przyczyniło się do urealnienia tych wartości. Kolejna zmiana w 2009 r. dotyczyła zmniejszenia stawek i uproszczenia skali (dwa zamiast trzech przedziałów), co spowodowało w tym roku duży spadek wpływów z PIT. W następnych latach ponownie, przez brak waloryzacji progu podatkowego oraz kwoty zmniejszającej podatek, pośrednie działania przyczyniły się do zwiększenia wpływów podatkowych.

Wśród pozostałych czynników wpływających na wysokość wpływów podatkowych należy wskazać: skuteczność i efektywność poboru podatków, jakość kontroli wywiązywania się podatników z zobowiązań ${ }^{27}$. Wymienione działania

${ }^{26}$ Problem analizował m.in. A. Wyszkowski, Zjawisko „zimnej progresji” w podatku dochodowym od osób fizycznych [w:] Dylematy i wyzwania finansów publicznych, red. T. Juja, seria „Zeszyty Naukowe Uniwersytetu Ekonomicznego w Poznaniu” nr 141, Poznań 2010.

27 Szczegółową analizę wymienionych czynników przeprowadziła m.in. E. Małecka-Ziembińska, Efektywność fiskalna podatku dochodowego, op. cit., s. 196 i n. 
prewencyjne, mimo ambiwalentnego na ogół postrzegania przez podatników, mogą odegrać ważną rolę ze względu na duże rozmiary luki podatkowej odzwierciedlającej przecież ubytek w szarej strefie gospodarki dochodów z podatków. Uszczelnienie systemu i ograniczenie oszustw podatkowych mogłyby pozwolić na pozytywne dla podatników zmiany (waloryzacja progu podatkowego, podniesienie kwoty wolnej od podatku nie tylko dla części podatników). Nie można jednak pomijać faktu istnienia zbyt wielu regulacji, które są za często zmieniane. A za jakość regulujących podatki przepisów odpowiada ustawodawca.

\section{Podatki dochodowe jako narzędzie polityki gospodarczej}

Za pomocą podatków, przede wszystkim dochodowych, kształtowane są relacje ekonomiczne między władzą publiczną a podatnikami. Akceptując pogląd, że opodatkowanie może pełnić funkcję stymulacyjną (wspieranie pożądanych celów gospodarczych, zachęcanie podatników do podejmowania określonych działań gospodarczych, kształtowanie ich decyzji bieżących i strategicznych ${ }^{28}$, należy rozważyć wpływ najważniejszych zmian konstrukcji CIT i PIT na poziom obciążeń podatkowych przedsiębiorców i ich zachowania. W artykule uwypuklono nominalne i efektywne stawki, podstawowe parametry stymulacji ekonomicznej. Te pierwsze, co prawda, nie odzwierciedlają skali rzeczywistych obciążeń, ale - jako informacja ogólnie dostępna - brane są pod uwage w pierwszej kolejności przy ocenie ciężaru podatkowego ${ }^{29}$. Drugie zaś, determinowane także pozostałymi elementami konstrukcji podatku (możliwymi preferencjami podatkowymi), pozwalają na ocenę rzeczywistego obciążenia dochodu podatkiem, co może być wykorzystywane do analiz porównawczych.

W CIT obowiązuje cały czas stawka proporcjonalna, a najważniejsze zmiany dotyczące nominalnego obciążenia miały miejsce do 2004 r. (zob. rysunek 1). Zmniejszenie stawek CIT w Polsce było zgodne z europejskimi tendencjami w opodatkowaniu przedsiębiorstw. Towarzyszyło temu jednak poszerzenie bazy podatkowej i zwiększenie podstawy opodatkowania, głównie przez likwidację lub ograniczenie istniejących preferencji ${ }^{30}$. Zwrócono już uwagę, że w latach 90. ubiegłego wieku państwo stworzyło w podatkach dochodowych rozbudowany system ulg. Mimo nie do końca pozytywnej oceny polityki podatkowej z punktu widzenia funkcji motywacyjnej ulgi inwestycyj-

${ }^{28}$ Szerzej zob. M. Jamroży, Podatkowe zachęty inwestycyjne dla przedsiębiorców, op. cit., s. 570 i n.

29 R. Dziemianowicz, Polityka podatkowa w państwach UE: wspótczesne trendy $i$ wyzwania. Dylematy i wyzwania finansów publicznych, red. T. Juja, seria "Zeszyty Naukowe”, nr 141, Wydawnictwo Uniwersytetu Ekonomicznego w Poznaniu, Poznań 2010, s. 401.

30 Światowe tendencje w opodatkowaniu przedsiębiorstw nakreślił m.in. A. Grycuk, Podatek CIT jako narzędzie polityki gospodarczej, „INFOS. Zagadnienia Społeczno-gospodarcze" 2010, nr 4(74). 
ne - zwłaszcza w latach 1994-1997 - miały istotny wpływ na redukcję stawki nominalnej (w 1996 r. względna różnica między nominalnym a efektywnym poziomem obciążenia CIT była najwyższa i wynosiła nawet 22,5\%). Później były to już stosunkowo nieliczne rozwiązania, w niewielkim zakresie wykorzystywane w celu oddziaływania na zachowanie podatników. Nieznaczny był zatem ich wpływ na efektywną stawkę opodatkowania i przekładało się to na malejącą względną różnicę między wysokością nominalnych stawek podatkowych a efektywnych (w ostatnich latach poniżej 10\%).

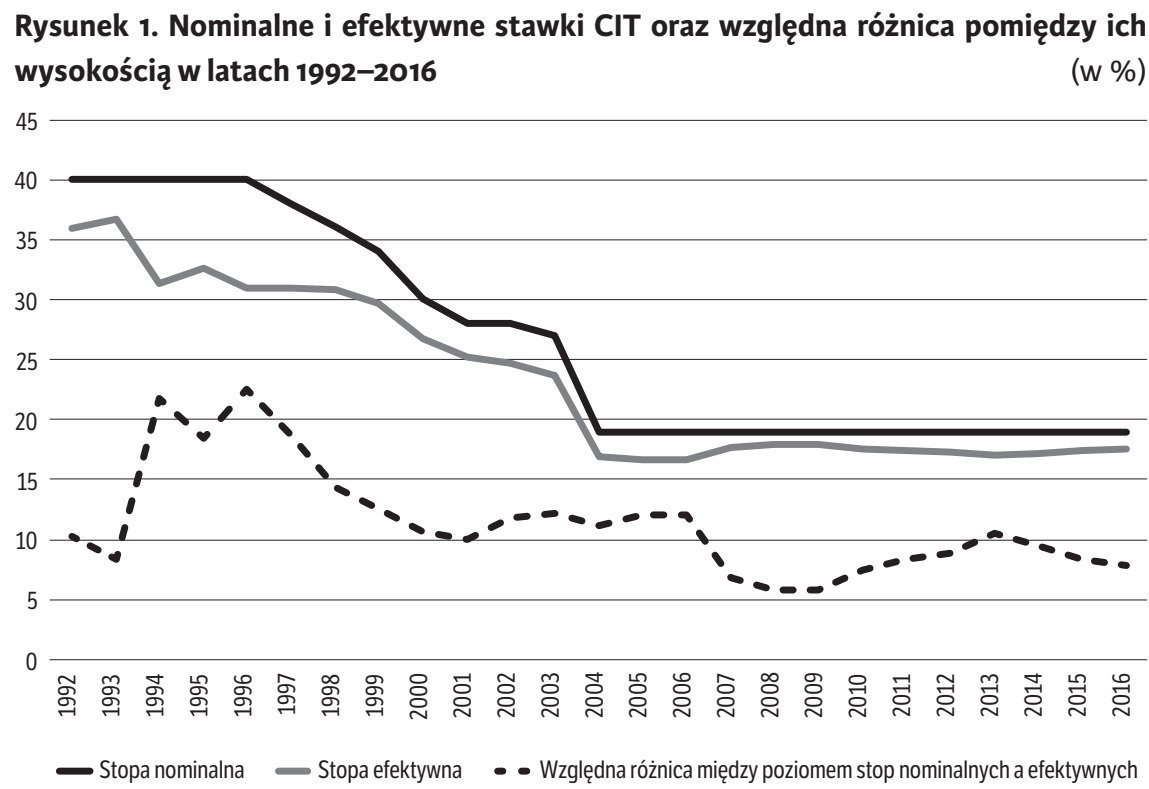

Źródło: na podstawie Informacja dotycząca rozliczenia podatku dochodowego od osób prawnych w latach 1992-2016, www.mf.gov.pl.

Jeśli chodzi o PIT, to analiza jest bardziej złożona, ponieważ w jego konstrukcji wprowadzano wielokrotnie różnego rodzaju zmiany (m.in. stawek podatkowych, progów podatkowych, kwot wolnych od opodatkowania, katalogu ulg podatkowych). Istotny dla poziomu efektywnego opodatkowania katalog preferencji podatkowych był konsekwentnie redukowany przez ustawodawcę. Szczegółowe badania na ten temat prowadził m.in. M. Sosnowski ${ }^{31}$. Z analiz

31 Zob. idem, Poziom progresywnego opodatkowania dochodów $z$ działalności gospodarczej osób fizycznych w Polsce w latach 2000-2006 [w:] Współczesne finanse. Stan i perspektywy rozwoju finansów publicznych, red. J. Głuchowski, Uniwersytet Mikołaja Kopernika w Toruniu, Torun 2008; idem, Wpływ zmian w konstrukcji podatku dochodowego od osób fizycznych na obciążenia fiskalne przedsiębiorstw [w:] Finanse - nowe wyzwania teorii i prak- 
wynika, że w latach 1999-2008 zauważalna była tendencja do spadku poziomu obciążeń nominalnych dla ogółu podatników (redukcja wynosiła ponad 5 pkt proc., względna 21\%), przy czym tylko dla podatników z III przedziału skali było to najbardziej wyraźne (ponad 5 pkt proc., względna zmiana ponad 15\%). Ponieważ do końca 2008 r. nie nastąpiła zmiana stawek podatkowych, zmniejszenie wysokości nominalnych obciążeń dochodu podatkiem można tłumaczyć wzrostem poziomu kwot dochodu wolnych od opodatkowania. Co ciekawe, znacznie mniejsza redukcja dotyczyła poziomu efektywnego obciążenia dochodu podatkiem. Dla ogółu badanej grupy podatników było to nieco ponad 2 pkt proc. (względnie 11,4\%). Na niższym poziomie agregacji danych widać natomiast, że w ciągu tych lat każda grupa podatników (wg przedziałów) mniej lub bardziej straciła - najwięcej podatnicy z ówczesnego II przedziału skali. Konkretny wniosek wynikający z przytoczonych badań jest następujący: stopniowe ograniczanie preferencji podatkowych skutkowało dla osób fizycznych prowadzących działalność gospodarczą na ogół wzrostem efektywnych obciążeń podatkowych.

Ponieważ, o czym już pisano, od 2009 r. nastąpiła zmiana konstrukcji skali podatkowej, warto przyjrzeć się danym dotyczącym późniejszego okresu. W latach 2009-2013 32 stawka nominalna dla ogółu podatników kształtowała się na poziomie zbliżonym (16,25-16,86\%; dla I przedziału: $15,35-15,67 \%$; a dla II przedziału skali: 20,49-22,03\%), co nie zaskakuje, ponieważ w tym okresie skala podatkowa pozostawała bez zmian. Odnosząc się do poziomu obciążeń podatkowych po uwzględnieniu preferencji wykorzystywanych przez przedsiębiorców (efektywne obciążenia podatkowe), można stwierdzić, że tu również zarysowała się tendencja utrwalania stabilizacji. To naturalne zjawisko, ponieważ zakres preferencji w poszczególnych latach był podobny. Przeciętne opodatkowanie PIT po odliczeniu składki na ubezpieczenie zdrowotne dla ogółu podatników wynosiło: 8,93-10\%; dla I przedziału skali: 7,58-8,38\%, a dla II przedziału skali: $16,63-18,44 \%$.

Koncepcja rozwiązania określanego podatkiem liniowym PIT o stawce $19 \%$ wywołała początkowo pewne kontrowersje. Zainteresowanie nim jednak rosło do 2008 r., kiedy to liczba podatników zwiększyła się prawie 2,5-krotnie z 200,2 tys. w 2004 r. do 463,1 tys. w 2008 r. Jej spadek nastąpił w 2009 r. (o 15,4\% w stosunku do 2008 r.), co zapewne wiązało się z obniżeniem stawek w skali progresywnej. W kolejnych latach można było zaobserwować rosnące z roku na rok zainteresowanie przedsiębiorców tą formą opodatkowania (w 2016 r. ponad 534 tys.). Dla wielu podatników to korzystna forma, niema-

tyki. Finanse publiczne red. L. Patrzałek, Wydawnictwo Uniwersytetu Ekonomicznego we Wrocławiu, Wrocław 2011.

32 Nie można było przytoczyć danych za kolejne lata, ponieważ od 2014 r. Ministerstwo Finansów ogranicza się do danych dla ogółu podatników, bez podziału na poszczególne źródła. 
jąca negatywnych skutków, jakie wiążą się z zastosowaniem stawek progresywnych. Co prawda, pozbawia ona prawa do ulg podatkowych, ale, jak dowiedziono, ich obecny katalog jest bardzo skromny. Decydując się więc na taki wybór opodatkowania dochodów, zamożniejsi podatnicy mają do dyspozycji większą część dochodów niż wtedy, gdy stosowali skalę progresywną.

Podsumowując analizy dotyczące PIT płaconego przez przedsiębiorców, można stwierdzić, że redukcja stawek w skali progresywnej, możliwość wyboru $19 \%$ podatku, to realne zmniejszenie ich obciążeń podatkowych, co może stanowić poważne ułatwienie działania na rynku i utrzymanie się na nim ${ }^{33}$. Odnosząc się z kolei do tematu opodatkowania dochodów uzyskiwanych z działalności gospodarczej (w różnych formach jej prowadzenia), trzeba przyznać, że powinny być traktowane jednakowo. Rozwój przedsiębiorstw przyczynia się do rozwoju całej gospodarki, dlatego też ich obciążenia powinny być tak skonstruowane, by w jak najmniejszym stopniu zniekształcać mechanizm rynkowy i nie ograniczać aktywności ekonomicznej. Niewątpliwie poruszone w tej części artykułu wielość i wysokość stawek to kategorie, które wydatnie przekładają się na obciążenie fiskalne. W badanym okresie były one w Polsce systematycznie obniżane, nie można jednak jednoznacznie stwierdzić, czy te korzystne dla przedsiębiorstw zmiany poziomu stawek przełożyły się na stopę wzrostu gospodarczego. O sile i kierunku tej zależności decyduje bardzo wiele czynników. Wysokość podatków nie jest jednak dla gospodarki obojętna. Konieczne jest zatem, co cały czas jest wielkim wyzwaniem dla konstruktorów systemu podatkowego, znalezienie równowagi między przedsiębiorcami i ich celami, a państwem i jego realizowanymi zadaniami. Priorytetem powinna stać się dbałość o szybki wzrost gospodarczy i budowa konkurencyjnej gospodarki ${ }^{34}$. Dlatego też rzeczą niekwestionowaną jest fakt, że tym, co w szczególny sposób ułatwia funkcjonowanie przedsiębiorstw, jest jakość systemu podatkowego. Wydaje się, że margines dalszego obniżania stawek w podatkach dochodowych oraz pole do poszerzenia bazy podatkowej, są ograniczone. Dlatego też, nawiązując do teorii optymalnego opodatkowania ${ }^{35}$, władza publiczna powinna podjąć działania prowadzące do zminimalizowania kosztów procesu fiskalnego.

\section{Społeczna rola podatków dochodowych}

Przyjmując, że w prowadzonej przez państwo polityce społecznej podstawowym celem redystrybucji jest bardziej równomierny podział dochodów, przyjrzyjmy się, jaki był rozkład podatków wg grup podatników płacących podatek

${ }_{33}$ M. Sosnowski, Wplyw zmian w konstrukcji podatku dochodowego, op. cit., s. 444.

${ }^{34}$ Ibidem, s. 445.

${ }_{35}$ Zob. F. Grądalski, System podatkowy w świetle teorii optymalnego opodatkowania, Wydawnictwo SGH, Warszawa 2006. 
w różnych przedziałach dochodowych oraz odsetek podatników korzystających z odliczeń ulg36 (tabele 3 i 4). W latach 2000-2008 średnio 94,33\% podatników znajdowało się w I przedziale, 4,59\% podatników w II przedziale i tylko $1,08 \%$ w III przedziale dochodowym. Progresja dotyczyła więc zaledwie ok. $6 \%$ podatników. Średnio 54,4\% wpływów podatkowych z tytułu PIT pochodziło od podatników mieszczących się w I przedziale, $19,17 \%$ w II i $26,43 \%$ w III przedziale opodatkowania. Ograniczeniu ulegał zakres instrumentów personalizacji podatkowej, co przełożyło się na coraz mniejszy odsetek podatników korzystających z ulg (początkowo nawet prawie 50\%, a w 2006 r. już tylko 26,4\%). W 2007 r. odsetek osób korzystających z odliczeń wzrósł do ok. $40 \%$, co było konsekwencją wprowadzenia nowej ulgi - na wychowanie dzieci. Warto zwrócić uwagę, że w badanym okresie prawie dwukrotnie więcej podatników z przedziału II i III korzystało z preferencji w porównaniu z osobami z I przedziału podatkowego. Ich beneficjentami byli więc głównie podatnicy o największych dochodach. Niewątpliwie wpływało to na wysokość ich obciążeń podatkowych i, co istotne w kontekście podjętych rozważań, wyraźnie spłaszczało progresję. A zatem PIT nie był tak silnie progresywny, jak mogła to sugerować wysokość stawek w skali obowiązującej do końca 2008 r. Nie można również pomijać rozwiązań dotyczących liczby i rozpiętości przedziałów skali podatkowej. To właśnie progi podatkowe mogą być wykorzystywane jako element realizacji polityki prorodzinnej państwa. Dalego też ustawodawca musi uwzględniać nie tylko ewentualne rozszerzenie progów podatkowych (łagodząc tym samym skutki podatkowe, w szczególności osób mniej zamożnych), ale także konieczność ich waloryzacji. W przeciwnym razie dochodzi do wzrostu realnego poziomu opodatkowania, a to prowadzi do zakłócenia efektywności realizacji funkcji redystrybucyjnej ${ }^{37}$. W Polsce, o czym wspomniano, sytuacja taka wystąpiła, co skutkowało także innymi niepożądanymi zdarzeniami (zmniejszenie ekonomicznej aktywności podatnika, większa skłonność podatników do uczestnictwa w gospodarce nieformalnej).

W wyniku zmian przeprowadzonych od 2009 r. pogłębiono spłaszczenie progresji podatkowej. Objęcie wyższą stawką w latach 2009-2016 jedynie średnio 2,4\% podatników, nadało temu podatkowi charakter quasi-liniowy. Zbudowana obecnie $\mathrm{z}$ dwóch szczebli podatkowych o znacznej rozpiętości stawek podatkowych skala podatkowa sprawia, że progresja w PIT ma jedynie pozor-

${ }^{36}$ Dane o grupie podatników korzystających z odliczeń ulg podatkowych dotyczą okresu 2000-2007, później Ministerstwo Finansów nie podawało już tak szczegółowych danych (z podziałem na progi podatkowe). To oczywiste, pamiętając, że katalog preferencji był ograniczany, co przełożyło się na coraz mniejszą liczbę podatników korzystających z ulg podatkowych.

37 W. Szymański, Diagnoza stanu obecnego i propozycje zmian systemowych w podatku PIT - przypadek Polska, „Pieniądze i Więź” 2015, nr 4(69), s. 69. 
Tabela 3. Podatnicy PIT i należny podatek wg przedziałów podatkowych w latach 2000-2008

\begin{tabular}{|c|c|c|c|c|}
\hline Rok & $\begin{array}{c}\text { Progi } \\
\text { podatkowe }\end{array}$ & $\begin{array}{l}\text { Struktura podatników } \\
(\%)\end{array}$ & $\begin{array}{l}\text { Podatek należny } \\
(\%)\end{array}$ & $\begin{array}{c}\text { Podatnicy korzystający } \\
\text { z odliczeń ulg } \\
\text { podatkowych } \\
(\%)\end{array}$ \\
\hline \multirow{4}{*}{2000} & 1 & 94,59 & 52,19 & 44,56 \\
\hline & II & 4,09 & 15,75 & 84,28 \\
\hline & III & 1,32 & 32,06 & 88,03 \\
\hline & Ogółem & 100,00 & 100,00 & 46,76 \\
\hline \multirow{4}{*}{2001} & 1 & 95,18 & 51,21 & 47,49 \\
\hline & II & 3,83 & 15,77 & 86,66 \\
\hline & III & 0,99 & 33,02 & 85,41 \\
\hline & Ogółem & 100,00 & 100,00 & 49,37 \\
\hline \multirow{4}{*}{2002} & 1 & 95,09 & 49,58 & 45,83 \\
\hline & II & 3,78 & 15,95 & 81,93 \\
\hline & III & 1,13 & 34,47 & 76,49 \\
\hline & Ogółem & 100,00 & 100,00 & 47,54 \\
\hline \multirow{4}{*}{2003} & I & 94,73 & 51,62 & 45,00 \\
\hline & II & 4,11 & 18,64 & 83,03 \\
\hline & III & 1,16 & 29,74 & 80,99 \\
\hline & Ogółem & 100,00 & 100,00 & 46,98 \\
\hline \multirow{4}{*}{2004} & 1 & 94,77 & 59,51 & 40,44 \\
\hline & II & 4,38 & 20,27 & 76,49 \\
\hline & III & 0,85 & 20,22 & 80,64 \\
\hline & Ogółem & 100,00 & 100,00 & 42,36 \\
\hline \multirow{4}{*}{2005} & 1 & 94,46 & 57,48 & 42,78 \\
\hline & II & 4,66 & 20,94 & 81,19 \\
\hline & III & 0,88 & 21,58 & 79,93 \\
\hline & Ogółem & 100,00 & 100,00 & 44,89 \\
\hline \multirow{4}{*}{2006} & 1 & 93,34 & 56,17 & 23,62 \\
\hline & II & 5,54 & 21,50 & 63,30 \\
\hline & III & 1,12 & 22,33 & 75,14 \\
\hline & Ogółem & 100,00 & 100,00 & 26,40 \\
\hline \multirow{4}{*}{2007} & 1 & 94,66 & 59,54 & 37,65 \\
\hline & II & 4,48 & 20,56 & 73,95 \\
\hline & III & 0,86 & 19,90 & 73,78 \\
\hline & Ogółem & 100,00 & 100,00 & 39,59 \\
\hline \multirow{4}{*}{2008} & 1 & 92,15 & 52,30 & b.d. \\
\hline & II & 6,45 & 23,19 & b.d. \\
\hline & III & 1,40 & 24,51 & b.d. \\
\hline & Ogółem & 100,00 & 100,00 & b.d. \\
\hline
\end{tabular}

Źródło: na podstawie Informacja dotyczaca rozliczenia podatku dochodowego od osób fizycznych $w$ latach 2000-2016, www.mf.gov.pl. 
Tabela 4. Podatnicy PIT i należny podatek wg przedziałów podatkowych w latach 2009-2016

\begin{tabular}{|c|c|c|c|}
\hline Rok & $\begin{array}{c}\text { Progi } \\
\text { podatkowe }\end{array}$ & Struktura podatników (\%) & Podatek należny (\%) \\
\hline \multirow{3}{*}{2009} & 1 & 98,41 & 76,97 \\
\hline & II & 1,59 & 23,03 \\
\hline & Ogółem & 100,00 & 100,00 \\
\hline \multirow{3}{*}{2010} & 1 & 98,11 & 77,32 \\
\hline & II & 1,89 & 22,68 \\
\hline & Ogółem & 100,00 & 100,00 \\
\hline \multirow{3}{*}{2011} & $\mathrm{I}$ & 97,86 & 76,28 \\
\hline & II & 2,14 & 23,72 \\
\hline & Ogółem & 100,00 & 100,00 \\
\hline \multirow{3}{*}{2012} & I & 97,69 & 73,44 \\
\hline & II & 2,31 & 26,56 \\
\hline & Ogółem & 100,00 & 100,00 \\
\hline \multirow{3}{*}{2013} & 1 & 97,53 & 75,28 \\
\hline & II & 2,47 & 24,72 \\
\hline & Ogółem & 100,00 & 100,00 \\
\hline \multirow{3}{*}{2014} & $\mathrm{I}$ & 97,30 & 74,45 \\
\hline & II & 2,70 & 25,55 \\
\hline & Ogółem & 100,00 & 100,00 \\
\hline \multirow{3}{*}{2015} & I & 97,11 & 74,12 \\
\hline & II & 2,89 & 25,88 \\
\hline & Ogółem & 100,00 & 100,00 \\
\hline \multirow{3}{*}{2016} & I & 96,96 & 73,89 \\
\hline & II & 3,04 & 26,11 \\
\hline & Ogółem & 100,00 & 100,00 \\
\hline
\end{tabular}

Źródło: jak pod tabelą 3.

ny charakter, co zdaniem niektórych badaczy, nie pozwala na dostosowanie wysokości obciążeń podatkowych do sytuacji dochodowej podatników ${ }^{38}$.

Przykładem rozwiązania prorodzinnego występującego w PIT od 2007 r. jest ulga na dzieci. W latach 2007-2013 przyjmowała formę ulgi bezzwrotnej ${ }^{39}$, skorzystało z niej rocznie ok. 4 mln podatników. Liczba dzieci, w stosunku do których rodzice skorzystali z ulgi, pozostawała stabilna i wynosiła średnio ok. 6,2 mln (tabela 5). Dane z 2013 r. nieco odbiegają od danych z lat poprzednich, co wynikało $\mathrm{z}$ istotnych zmian (prawo do odliczenia wyższych kwot w stosunku do kwot obowiązujących wcześniej na trzecie, czwarte i kolejne dziecko;

38 R. Zieliński, Instrumenty personalizacji podatkowej w konstrukcji podatku dochodowego od osób fizycznych, „Annales Universitatis Mariae Curie-Skłodowska, sectio H (Oeconomia)" 2016, Vol. 50, No 1, s. 706-707, https://doi.org/10.17951/h.2016.50.1.701.

39 Po spełnieniu warunków można było odliczyć jedynie tyle, na ile umożliwiała to wielkość płaconego przez podatnika podatku, a właściwie determinujący jego wysokość dochód. 
Tabela 5. Wykorzystanie ulgi prorodzinnej w latach 2007-2013

\begin{tabular}{|l|r|r|r|r|r|r|r|}
\hline \multicolumn{1}{|c|}{ Wyszczególnienie } & 2007 & 2008 & 2009 & 2010 & 2011 & 2012 & 2013 \\
\hline Liczba dzieci (tys.) & 6017 & 6358 & 6275 & 6287 & 6294 & 6167 & 5825 \\
\hline Liczba podatników(tys.) & 3974 & 4206 & 4337 & 4303 & 4364 & 4334 & 4024 \\
\hline Kwota odliczeń (mld zł) & 5,43 & 6,04 & 5,63 & 5,68 & 5,74 & 5,70 & 5,53 \\
\hline Przeciętna kwota odliczenia na 1 dziecko (zł) & 903 & 951 & 898 & 904 & 912 & 924 & 949 \\
\hline Przeciętna kwota odliczenia na 1 podatnika (zł) & 1367 & 1437 & 1299 & 1321 & 1315 & 1315 & 1374 \\
\hline
\end{tabular}

Źródło: jak pod tabelą 3.

Tabela 6. Wykorzystanie ulgi prorodzinnej w latach 2014-2016

\begin{tabular}{|l|c|r|r|}
\hline \multicolumn{1}{|c|}{ Wyszczególnienie } & 2014 & \multicolumn{1}{c|}{2015} & 2016 \\
\hline Liczba dzieci (tys.) & 6468 & 6484 & 6419 \\
\hline Liczba podatników (tys.) & b.d. & 4505 & 4474 \\
\hline Kwota odliczona od podatku powiększona & & & \\
o zwrot nieodliczonej ulgi (mld zł) & 6,93 & 6,98 & 6,93 \\
- kwota odliczeń & 5,59 & 5,62 & 5,62 \\
- kwota zwrotu nieodliczonej ulgi & 1,34 & 1,36 & 1,31 \\
\hline Przeciętna kwota odliczenia na 1 dziecko (zł) & 1071 & 1077 & 1080 \\
\hline Przeciętna kwota odliczenia na 1 podatnika (zł) & 1380 & 1550 & 1550 \\
\hline
\end{tabular}

Źródło: jak pod tabelą 3.

ograniczenie prawa do ulgi podatnikom sprawujących opiekę nad jednym dzieckiem).

Kolejne zmiany formuły preferencji, obowiązujące od 2014 r. wynikały z faktu, że wsparcie rodzin o niskich dochodach, mających na utrzymaniu dużo dzieci, nie było realizowane w wystarczającym stopniu. Stąd ważna zmiana, polegająca na tym, że nieodliczona ze względu na zbyt niski podatek część ulgi prorodzinnej będzie podatnikowi zwracana (wypłata ekwiwalentu za niewykorzystaną część przysługującej ulgi), jednak w kwocie nie wyższej niż suma składek na ubezpieczenia społeczne i zdrowotne obliczona w składanym zeznaniu podatkowym. Na skutek tych pozytywnych zmian znacznie zwiększyło się grono podatników, którzy mogą skorzystać z odliczenia. Zwiększyły się także pozostałe istotne dla ulgi wielkości, co było konsekwencją umożliwienia podatnikom realizacji pełnego odliczenia niezależnie od poziomu wypracowanego dochodu (tabela 6).

Do grupy rozwiązań prorodzinnych, także powszechnie wykorzystywanych, należy wspólne rozliczanie się z małżonkiem oraz osób samotnie wychowujących dzieci. Analizując dane za okres 2000-2016, można jednak odnotować systematyczny spadek liczby podatników rozliczających się na tych zasadach. W 2000 r. odsetek podatników korzystających ze wspólnego opodatkowania małżonków wynosił 61,66\%, w 2008 r. (ostatnim, kiedy obowiązywała trzyszczeblowa skala podatkowa) - 40,01\%, a w 2016 r. - 36,62\%. Spadek nie dziwi, spowodowany był bowiem sygnalizowanymi zmianami. Dwuszczeblo- 
wa konstrukcja skali podatkowej, a także mniejsza niż w poprzednich latach różnica między stawką najniższą a najwyższą, w oczywisty sposób obniżają potencjalne korzyści wynikające ze wspólnego opodatkowania. Nie można jednak pomijać i innych czynników - zmian społeczno-kulturowych w społeczeństwie (wzrost liczby rozwodów, spadek liczby związków formalnych).

Z przeprowadzonych analiz wynika, że PIT, poza wyjątkami, w ostatnich latach zawierał mało elementów, które czynią z niego prospołeczne rozwiązanie. Takimi rozwiązaniami mogłyby być m.in.: wieloszczeblowa skala podatkowa przy zmiennej rozpiętości przedziałów w powiązaniu z wyższą kwotą wolną od podatku; powiązanie kwoty wolnej od podatku z minimum socjalnym.

\section{Podsumowanie}

W wyniku przeprowadzonej syntetycznej i niepełnej - ze względu na ograniczenia ramowe - oceny funkcjonowania w Polsce podatków dochodowych można pokusić się o kilka wniosków. Przede wszystkim należy jednak zaznaczyć, że w przypadku podatków, zwłaszcza opodatkowania dochodów, trudno o jednoznaczną ocenę i wynikające $\mathrm{z}$ niej proponowane zmiany w polskim systemie podatkowym. Oddziaływanie podatków jest przecież niejednokrotnie złożone i dotyczy wielu obszarów społeczno-gospodarczych. Uznano, że właściwym sposobem oceny podatków dochodowych będzie analiza z punktu widzenia wypełniania przez nie przynależnych im funkcji fiskalnych i pozafiskalnych.

Wpływy uzyskiwane $\mathrm{z}$ podatków dochodowych były na ogół stabilne i pewne. Co prawda, nie stanowiły one pierwszoplanowego źródła dochodów budżetu państwa, to jednak spostrzeżenie to nie znajduje potwierdzenia przy uwzględnieniu innych segmentów sektora finansów publicznych, do których kierowane są wpływy z podatków dochodowych. Jak wynika z niektórych badań, podatki dochodowe, zwłaszcza PIT, zawierały pewne elementy, które czynią z nich relatywnie stabilne źródło dochodów publicznych w okresie kryzysu gospodarczego ${ }^{40}$. Wydajność podatków dochodowych jest uzależniona m.in. od ich konstrukcji, spójności i przejrzystości regulujących je przepisów. Kluczowe są: zakres podmiotowy i przedmiotowy, skala podatkowa oraz preferencje podatkowe. Niektóre elementy konstrukcji podatków dochodowych, czego jednak ze względu na brak wiarygodnych danych nie zbadano w artykule, mogą powodować wzrost kosztów ich wymiaru i poboru, ograniczając tym samym możliwość wzrostu wpływów z ich tytułów. Pozostałymi, także istotnymi, czynnikami wpływającymi na wysokość wpływów z podatków do-

${ }^{40}$ Zob. m.in. E. Małecka-Ziembińska, Efektywność fiskalna podatku dochodowego, op. cit.; J. Połczyński, Podatek od dochodów osobistych jako stabilizator dochodów publicznych $w$ Polsce w dobie kryzysu [w:] Finanse - nowe wyzwania teorii i praktyki. Finanse publiczne, red. L. Patrzałek, Wydawnictwo Uniwersytetu Ekonomicznego we Wrocławiu, Wrocław 2011. 
chodowych są: przebieg koniunktury gospodarczej, sprawność administracji skarbowej oraz samych podatników, a w zasadzie ich gotowość do ponoszenia ciężaru opodatkowania czy skłonność do ucieczki przed podatkami.

Podatki dochodowe, co nie budzi wątpliwości, zniekształcają decyzje podejmowane przez przedsiębiorstwa. Dlatego tak ważne dla konstruktorów systemu podatkowego powinno być właściwe zdefiniowanie i wdrożenie najważniejszych kategorii, decydujących o zniekształcaniu mechanizmu rynkowego i ograniczaniu aktywności ekonomicznej, aby skala ich negatywnego oddziaływania była możliwie jak najmniejsza. Władza publiczna odpowiedzialna jest zatem za tworzenie sprzyjających warunków dla działalności gospodarczej. Polityka podatkowa wielu państw europejskich zakłada wykorzystanie progresji podatkowej do łagodzenia nadmiernego zróżnicowania dochodowego społeczeństwa. Nie może być ona jednak analizowana wyłącznie w kontekście idei sprawiedliwości podatkowej. Zwraca się również uwagę na negatywne oddziaływanie podatków progresywnych na efektywność gospodarowania (ograniczenie przedsiębiorczości, hamowanie inicjatyw gospodarczych, brak zainteresowania wzrostem rentowności, zatajanie źródeł dochodów ${ }^{41}$. W efekcie przedsiębiorcy, chcąc wynagrodzić sobie przymus płacenia wysokich podatków, przerzucają je na innych. Postrzeganie podatku progresywnego jako antybodźca dla rozwoju i osiągania coraz wyższych dochodów, zwłaszcza dochodów z kapitału (zyski inwestycyjne, odsetki, dywidendy), stanowiło impuls do rewizji filozofii polityki podatkowej i zastosowania rozwiązań ze stawkami proporcjonalnymi.

Na tle dotychczasowych rozważań rodzą się więc następujące konkluzje. Pożądane byłoby, w kontekście przejrzystości i możliwości przyjęcia różnych koncepcji opodatkowania, odrębne uregulowanie dochodów uzyskiwanych z pracy i z kapitału. Zasadne wydaje się także „włączenie”, ale z uwzględnieniem specyfiki, osób fizycznych prowadzących działalność gospodarczą do systemu podatku dochodowego osób prawnych. Oczywiście, pozostaje problem konkretnych rozwiązań fiskalnych, np. utrzymania dużo wyższego opodatkowania pracy niż kapitału, czy też - jak proponują niektórzy ekonomiści uwzględniająca bardziej prospołeczne niż sprzyjające biznesowi nastawienie polityki fiskalnej, zmiana proporcji między opodatkowaniem pracy i kapita$\mathfrak{ł u}^{42}$. Zarysowane propozycje nie mogą być oczywiście postrzegane jako cało-

${ }^{41}$ Zob. w: M. Sosnowski, Opodatkowanie dochodów osób fizycznych na zasadach ogólnych w Polsce w latach 1998-2007 - wybrane zagadnienia, „Zeszyty Naukowe Uniwersytetu Szczecińskiego, Ekonomiczne Problemy Usług” 2009, nr 546 (Finanse 2009 - Teoria i praktyka. Finanse publiczne), s. 359-360.

${ }^{42}$ Zwolennikiem takiego rozwiązania jest np. H. Kuzińska, Prospołeczne propozycje polskiego systemu podatkowego. Wybrane zagadnienia, „Annales Universitatis Mariae Curie-Skłodowska, sectio H (Oeconomia)" 2016, Vol. 50, No 1, https://doi. org/10.17951/h.2016.50.1.681. 
ściowe usprawnienie polskiego systemu podatkowego, pominięto tu bowiem ważny problem proporcji obciążeń podatkami pośrednimi i bezpośrednimi. Miały one jedynie na celu podkreślenie specyfiki opodatkowania dochodów z pracy i dochodów z kapitału.

Kolejna ważna dla obywateli sprawa, to kwestia, czy podatki dochodowe, a w zasadzie system podatkowy powinien wypełniać funkcję społeczną? Rację ma cytowana już H. Kuzińska, pisząc, że w dużym stopniu determinowane jest to poziomem rozwarstwienia dochodowego i skalą zagrożenia ubóstwem ${ }^{43}$. Wydaje się, że podobnie jak w przypadku wpływu podatków dochodowych na sferę gospodarczą, niezbędne jest znalezienie pewnej równowagi, nie można bowiem pomijać kwestii dotyczącej sprawiedliwego podziału produktu i dochodu wytworzonego przez rynek. Dla części społeczeństwa (adresatów transferów budżetowych) funkcja redystrybucyjna oznacza nie tylko wyrównywanie stanu majątkowego, ale także zwiększenie stabilności dochodów. Wymaga to jednak odpowiedniego i wyważonego doboru instrumentów personalizacji podatkowej w konstrukcji PIT. Poza odpowiednią taryfą podatkową mogą to być skuteczne ulgi prorodzinne ${ }^{44}$.

Podsumowując, należy stwierdzić, że obecny polski system opodatkowania dochodów osób fizycznych i prawnych nie jest systemem idealnym. Nie odbiega on jednak istotnie od systemów podatkowych większości krajów UE. Ma pewne zalety, ale i mankamenty. Nie ulega wątpliwości, że konieczne są także zmiany, które będą właściwe nie tylko z punktu widzenia kształtowania się w przyszłości wpływów budżetowych, ale również stworzenia odpowiednich ram dla dynamicznego rozwoju aktywności gospodarczej przedsiębiorstw oraz skutecznego łagodzenia nadmiernych nierówności dochodowych w społeczeństwie ${ }^{45}$.

\section{Bibliografia}

Bolkowiak I., System podatkowy a polityka społeczno-gospodarcza w latach 1989-1993, Instytut Finansów, Warszawa 1994.

Budlewska R., Ulga na dzieci jako instrument realizacji polityki prorodzinnej w Polsce, „Annales Universitatis Mariae Curie-Skłodowska, sectio H (Oeconomia)” 2016, Vol. 50, No 1, https://doi.org/10.17951/h.2016.50.1.725.

${ }^{43}$ Ibidem, s. 682

${ }^{44}$ Tego typu narzędzia powinny realizować trzy cele. Po pierwsze, powinny poprawiać redystrybucję dochodów, gwarantując pożądany standard życia osób o niskich dochodach. Po drugie, powinny zapobiegać odpływowi siły roboczej z rynku pracy, motywując ludzi do zapewnienia sobie finansowej samowystarczalności. Po trzecie, powinny realizować wymienione cele w sposób kosztowo efektywny. Zob. L. Morawski, Ulga podatkowa $z$ tytułu wychowywania dzieci - efekty i propozycja zmian, „Polityka Społeczna” 2010, nr 1, s. 8.

${ }_{45}$ Ciekawe propozycje w tym zakresie zgłosił m.in. J. Kulicki, zob. Reforma opodatkowania dochodów, op. cit. 
Dziemianowicz R., Polityka podatkowa w państwach UE: współczesne trendy $i$ wyzwania, „Zeszyty Naukowe Uniwersytetu Ekonomicznego w Poznaniu” 2010, nr 141 (Dylematy i wyzwania finansów publicznych, red. T. Juja).

Felis P., Funkcjonowanie ulg inwestycyjnych w podatku dochodowym od osób prawnych w latach 1994-1999 - próba oceny, seria „Studia i Prace Kolegium Zarządzania i Finansów", z. 25, Warszawa 2002.

Felis P., Podatki od nieruchomości a polityka podatkowa gmin w Polsce, Wydawnictwo SGH, Warszawa 2015.

Felis P., Wybrane rozwiązania opodatkowania matych przedsiębiorstw - ocena i proponowane kierunki zmian, „Studia BAS” 2014, nr 1(37), (Rozwój przedsiębiorczości oraz sektora małych i średnich przedsiębiorstw, red. G. Gołębiowski).

Grądalski F., System podatkowy w świetle teorii optymalnego opodatkowania, Wydawnictwo SGH, Warszawa 2006.

Grycuk A., Podatek CIT jako narzędzie polityki gospodarczej, „INFOS. Zagadnienia Społeczno-gospodarcze" 2010, nr 4(74).

Ickiewicz J., Obciążenia fiskalne przedsiębiorstw, PWE, Warszawa 2009.

Informacja dotycząca rozliczenia podatku dochodowego od osób fizycznych w latach 2000-2016, www.mf.gov.pl.

Informacja dotycząca rozliczenia podatku dochodowego od osób prawnych $w$ latach 1992-2016, www.mf.gov.pl.

Jamroży M., Podatkowe zachęty inwestycyjne dla przedsiębiorców [w:] Finanse - nowe wyzwania teorii i praktyki. Finanse przedsiębiorstw, red. S. Wrzosek, Wydawnictwo Uniwersytetu Ekonomicznego we Wrocławiu, Wrocław 2011.

Kotlarek N., Ulga z tytułu nabycia nowych technologii - mankamenty konstrukcji i propozycje modyfikacji, „Annales Universitatis Mariae Curie-Skłodowska, sectio H (Oeconomia)" 2016, Vol. 50, No 1, https://doi.org/10.17951/h.2016.50.1.529.

Kulicki J., Reforma opodatkowania dochodów [w:] Dylematy reformy systemu podatkowego w Polsce, red. H. Dzwonkowski, J. Kulicki, Wydawnictwo Sejmowe, Warszawa 2016.

Kuzińska H., Prospołeczne propozycje polskiego systemu podatkowego. Wybrane zagadnienia, „Annales Universitatis Mariae Curie-Skłodowska, sectio H (Oeconomia)” 2016, Vol. 50, No 1, https://doi.org/10.17951/h.2016.50.1.681.

Małecka-Ziembińska E., Efektywność fiskalna podatku dochodowego od osób fizycznych w Polsce, Wydawnictwo Uniwersytetu Ekonomicznego w Poznaniu, Poznań 2012.

Morawski L., Ulga podatkowa z tytułu wychowywania dzieci - efekty i propozycja zmian, „Polityka Społeczna” 2010, nr 1.

Owsiak S., System podatkowy Polski w okresie transformacji - próba oceny, „Annales Universitatis Mariae Curie-Skłodowska, sectio H (Oeconomia)” 2016, Vol. 50, No 1, https://doi.org/10.17951/h.2016.50.1.15.

Połczyński J., Podatek od dochodów osobistych jako stabilizator dochodów publicznych $w$ Polsce $w$ dobie kryzysu [w:] Finanse - nowe wyzwania teorii i praktyki. Finanse publiczne red. L. Patrzałek, Wydawnictwo Uniwersytetu Ekonomicznego we Wrocławiu, Wrocław 2011. 
Sosnowski M., Opodatkowanie dochodów osób fizycznych na zasadach ogólnych w Polsce w latach 1998-2007 - wybrane zagadnienia, „Zeszyty Naukowe Uniwersytetu Szczecińskiego, Ekonomiczne Problemy Usług” 2009, nr 546 (Finanse 2009 - Teoria i praktyka. Finanse publiczne).

Sosnowski M., Poziom progresywnego opodatkowania dochodów z działalności gospodarczej osób fizycznych $w$ Polsce w latach 2000-2006 [w:] Współczesne finanse. Stan i perspektywy rozwoju finansów publicznych, red. J. Głuchowski, Uniwersytet Mikołaja Kopernika w Toruniu, Toruń 2008.

Sosnowski M., Wplyw zmian w konstrukcji podatku dochodowego od osób fizycznych na obciążenia fiskalne przedsiębiorstw [w:] Finanse - nowe wyzwania teorii i praktyki. Finanse publiczne, red. L. Patrzałek, Wydawnictwo Uniwersytetu Ekonomicznego we Wrocławiu, Wrocław 2011.

Szymański W., Diagnoza stanu obecnego i propozycje zmian systemowych w podatku PIT - przypadek Polska, „Pieniądze i Więź” 2015, nr 4(69).

Ślesicka A., Stosowanie ulg i zwolnień w podatku dochodowym od osób fizycznych w państwach UE, „Studia BAS” 2008, nr 14, t. 1 (Tendencje w opodatkowaniu dochodów osób fizycznych w państwach UE, red. M. Korolewska).

Wplywy budżetowe za okres od 1 stycznia 2003 r. 31 grudnia 2016 r., www.mf.gov.pl.

Wyszkowski A., Zjawisko „zimnej progresji” w podatku dochodowym od osób fizycznych [w:] Dylematy i wyzwania finansów publicznych, red. T. Juja, seria „Zeszyty Naukowe Uniwersytetu Ekonomicznego w Poznaniu” nr 141, Poznań 2010.

Zieliński R., Instrumenty personalizacji podatkowej w konstrukcji podatku dochodowego od osób fizycznych, „Annales Universitatis Mariae Curie-Skłodowska, sectio H (Oeconomia)" 2016, Vol. 50, No 1, https://doi.org/10.17951/h.2016.50.1.701.

\section{Akty prawne}

Ustawa z 28 lipca 1983 r. o podatku od spadków i darowizn, t.j. Dz.U. 2017, poz. 833, ze zm.

Ustawa z 15 listopada 1984 r. z podatku rolnym, t.j. Dz.U. 2017, poz. 1892.

Ustawa z 31 stycznia 1989 r. o podatku dochodowym od osób prawnych, Dz.U. nr 3, poz. 12 , ze zm.

Ustawa z 26 lipca 1991 r. o podatku dochodowym od osób fizycznych, t.j. Dz.U. 2016, poz. 2032, ze zm.

Ustawa z 15 lutego 1992 r. o podatku dochodowym od osób prawnych, t.j. Dz.U. 2016, poz. 1888 , ze zm.

Ustawa z 20 listopada 1998 r. o zryczałtowanym podatku dochodowym od niektórych przychodów osiąganych przez osoby fizyczne, t.j. Dz.U. 2017, poz. 2157.

Ustawa z 30 października 2002 r. o podatku leśnym, t.j. Dz.U. 2017, poz. 821.

Ustawa z 24 sierpnia 2006 r. o podatku tonażowym, t.j. Dz.U. 2014, poz. 511, ze zm. 